\title{
Reactions of Nitroso Hetero Diels-Alder Cycloadducts with Azides: Stereoselective Formation of Triazolines and Aziridines
}

\author{
Brian S. Bodnar and Marvin J. Millera,b \\ a251 Nieuwland Science Hall, Department of Chemistry and Biochemistry, University of Notre \\ Dame, Notre Dame, Indiana 46556. \\ bLeibniz-Institute for Natural Product Research and Infection Biology, Hans Knöll Institute, \\ Beutenbergstrasse 11a, 07745, Jena, Germany.
}

\section{Abstract}

The addition of azides to acylnitroso hetero Diels-Alder cycloadducts derived from cyclopentadiene affords exo triazolines in excellent yield. The reaction is greatly affected by reducing the level of alkene strain, while sterically demanding azides do not hinder the reaction. Conversion of the triazolines to aziridines is also described.

\begin{abstract}
The nitroso hetero Diels-Alder (HDA) reaction provides a useful method for incorporating 1,4-aminoalcohol moieties into a carbon framework in a diastereoselective fashion. ${ }^{1}$ Stereoselective nitroso HDA reactions ${ }^{2}$ have also provided access to new classes of synthetically useful molecules. While a variety of nitroso species have been investigated for use in HDA reactions, ${ }^{3}$ our research has largely focused on acyl- and carboxylnitroso species due to the ease of their synthesis and high reactivity. Hydroxamic acids and $N$ hydroxy carbamates, when oxidized in the presence of cyclic dienes, afford hetero DielsAlder adducts 1. ${ }^{1 \mathrm{a}, 4}$ Reduction of the N-O bond of $\mathbf{1}$ results in amino alcohols, ${ }^{5}$ which are suitable intermediates for the synthesis of natural products, ${ }^{6}$ carbocyclic nucleosides, ${ }^{7}$ and other important biologically active molecules. ${ }^{8}$ The $\mathrm{C}-\mathrm{O}$ bond can also be cleaved through metal-mediated reactions in the presence of nucleophiles ${ }^{9}$ or electrophiles, ${ }^{10}$ yielding $1,4-$ benzodiazepines ${ }^{11}$ and other useful synthetic intermediates. The $N$-acyl group can also be cleaved under relatively mild conditions (where $\mathrm{R}=$ alkyl or aryl). ${ }^{12}$ While extensive chemistry has been developed that capitalizes on the strained nature of $\mathbf{1}$, modifications of the olefin have been mainly limited to epoxidation, ${ }^{6 c}$ dihydroxylation, ${ }^{13}$ and oxidative cleavage. $^{14}$
\end{abstract}

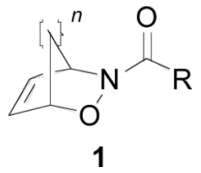

Correspondence to: Marvin J. Miller.

mmiller1@nd.edu .

Supporting Information Available: Experimental details and characterization data for triazolines 5a-e, 6a-e, 9-12, and 14-16, including 1D and 2D-NMR spectra and x-ray crystallographic data. This material is available free of charge via the Internet at http://pubs.acs.org. 
In an effort to expand upon the versatility of $\mathbf{1}$, we were interested in selective functionalization of the olefin to produce new structural features. Encouraged by a recent report highlighting the addition of nitrile oxides to $\mathbf{1},{ }^{15}$ we wish to report on studies regarding the reactivity of $\mathbf{1}$ with azides to form triazolines and their subsequent transformation to aziridines.

Intermolecular [3+2] cycloaddition reactions of azides to strained bicyclic alkenes are welldocumented in the literature. ${ }^{16}$ Examples include additions to norbornene, 2azabicyclo[2.2.1] hept-5-en-3-one (ABH) 2 to afford 2'-3'-epimino-carbocyclic nucleosides, ${ }^{17}$ 2,3-diazabicyclo[2.2.1] hept-5-enes 3 to afford 1,4-dihydropyridines, ${ }^{18}$ as well as many other strained systems. ${ }^{16 \mathrm{~h}, 19}$ However, the addition of azides to bicyclic oxazines such as $\mathbf{1}$ has not been disclosed in the literature.
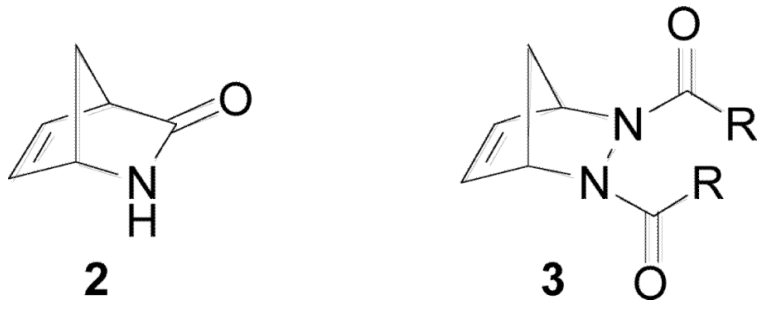

Since we wished to probe the role of olefin strain on reactivity with azides, we chose to subject the olefins of 1a-c as well as protected amino alcohols 4a-c to reactions with various azides (Scheme 1). Oxazines 1a-c can be prepared on a large scale from hydroxylamine hydrochloride in two steps in moderate to high yields. ${ }^{20} \mathrm{~N}-\mathrm{O}$ bond reduction with $\mathrm{Mo}(\mathrm{CO})_{6}{ }^{21}$ followed by protection of the resulting alcohol yielded monocyclic olefins $4 \mathbf{4}$ c. $^{22}$

We were very pleased to find that when $1 \mathbf{a}$ was treated with benzyl azide, ${ }^{23}$ the regioisomeric exo-triazolines $5 \mathbf{a}$ and $6 \mathbf{a}$ were obtained in quantitative yield after stirring for 2 days neat at room temperature (eq 1). Similar reactions of 2-azabicyclo[2.2.2] hept-5-en-3ones reportedly required high pressures for the cycloaddition reaction to occur. ${ }^{17 \mathrm{c}}$ The exospecificity of the reaction is in agreement with what has been reported in the literature in related reactions of bicyclo[2.2.1] hept-5-ene-2,3-dicarboximides, ${ }^{16 \mathrm{~h}} \mathrm{ABH}(2)$ and derivatives, ${ }^{24}$ 7-oxabicyclo[2.2.1] hept-5-en-2-yl derivatives, and 3, ${ }^{18,25}$ and was confirmed by single crystal $\mathrm{x}$-ray diffraction of triazolines $\mathbf{5 a}$ and $\mathbf{6 a}$.

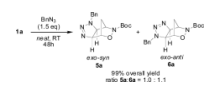

In an effort to ascertain the limitations of this chemistry, we treated alkene 1a with various organic azides under a number of reaction conditions (Table 1). The reaction proceeded equally well refluxing in toluene or chloroform (entries 4 and 8), however it was sluggish when stirred in solution at room temperature (entry 2). The steric bulk of the azide had little effect on either the regioselectivity or yield of the reaction, with primary, secondary, tertiary, and aryl azides affording triazolines 5 and $\mathbf{6}$ in excellent yield (entries 8-12).

The structures of $\mathbf{5}$ and $\mathbf{6}$ were assigned based on single crystal x-ray diffraction for $\mathbf{5 a}$ and 6a, and by 2D-NMR experiments for 5b-e and $\mathbf{6 b}-\mathbf{e}$. The exo stereochemistry was confirmed from the observed ${ }^{4} J$-coupling ("W-coupling") of $\mathrm{H}_{2}$ and $\mathrm{H}_{3}$ with $\mathrm{H}^{5}$ ', but not with $\mathrm{H}^{5}$. The position of the Boc group relative to the $\mathrm{R}$ group was confirmed by HMBC experiments based on the observed ${ }^{3} J$-coupling between $\mathrm{H}^{4}$ (or $\mathrm{H}^{1}$ ) and the carbonyl (Figure 1). ${ }^{26}$ 
Trimethylsilyl azide has been reported to add to norbornene systems and other bicyclic olefins to yield triazolines and/or aziridines directly. ${ }^{18,27}$ Since we were interested in obtaining the unsubstituted aziridine 7, 1a was subjected to azidotrimethylsilane under various conditions (Scheme 2). Under a variety of reaction conditions (neat, $25-80^{\circ} \mathrm{C}$, $\mathrm{PhCH}_{3}, 25-110^{\circ} \mathrm{C}$ ), only decomposition of the alkene was observed. Tosyl azide ${ }^{28}$ has also been reported to afford aziridines directly, ${ }^{17 b}$ and upon treatment of $\mathbf{1 a}$ with tosyl azide, we were able to obtain aziridine $\mathbf{8}$ in good yield.

Substantial rate increases were reported for [3+2] cycloadditions (especially "Click chemistry" 29 reactions) when both reactants were "floated" on water compared to reactions that were stirred with or without solvent. ${ }^{30} \mathrm{We}$ found no significant increase in the rate of reaction when 1a was treated with benzyl azide "on water" or in a concentrated solution of toluene "on water" when compared to stirring the two reagents neat at room temperature.

The effect of the strain of the alkene on the formation of triazolines was also studied. When the bicyclo[2.2.2] cycloadduct $\mathbf{1 b}$ was treated with 1.4 equivalents of benzyl azide neat at room temperature, no reaction was observed. When $\mathbf{1 b}$ was treated with a large excess of benzyl azide in refluxing toluene, however, a mixture of triazolines 9-12 was obtained in moderate yield (Scheme 3). In contrast to bicyclo[2.2.1] cycloadduct 1a, endo triazolines 11 and $\mathbf{1 2}$ were formed along with the exo triazolines $\mathbf{9}$ and 10. The influence of ring strain on reactivity was especially evident when bicyclo[2.2.4] cycloadduct $1 \mathbf{c}$ and monocyclic alkenes 4a-c were subjected to the same conditions. When heated neat or in toluene, only trace amounts of triazoline products were observed.

In the course of this study, we found that triazolines $5 \mathbf{a}$ and $\mathbf{6 a}$ were stable to temperatures up to $120^{\circ} \mathrm{C}$ and did not decompose readily in ambient light. When irradiated below $\sim 300$ $\mathrm{nm}, \mathbf{5 a}$ and 6a readily underwent photolytic conversion to aziridine $\mathbf{1 3}$ in 2-4 h (Table 2). At wavelengths higher than $300 \mathrm{~nm}$, the time required for the reaction to proceed to $100 \%$ conversion increased greatly (entry 5 ).

Surprisingly, N-O bond reduction of triazolines 5a and $6 \mathbf{a}$ proceeded cleanly to afford triazolines 14 and 15 without decomposition of the triazoline ring (Scheme 4). Triazoline 14 was cleanly transformed to aziridine $\mathbf{1 6}$ upon irradiation in acetonitrile; however, a complex mixture of products was observed when triazoline $\mathbf{1 5}$ was subjected to the same conditions. The reason for this result is unclear at this time and will be investigated further.

In summary, the addition of azides to the electron-neutral alkene of cycloadduct 1a affords a mixure of exo triazolines in good to excellent yield. The steric bulk of the azide appears not to play a significant role in the course of the reaction; however, the reactivity of the alkene was diminished significantly with cycloadducts derived from larger cyclic alkenes (1b and 1c), or monocyclic alkenes (4a-c).

\section{Experimental Section}

\section{General Procedure for the Synthesis of Triazolines Using Method A}

The alkene $(1 \mathrm{mmol})$ and azide $(1.5 \mathrm{mmol})$ were combined and stirred neat at $25^{\circ} \mathrm{C}$ in a single-necked round-bottomed flask. The progress of the reaction was monitored by TLC or ${ }^{1} \mathrm{H}$ NMR for the disappearance of the alkene, and the crude material was chromatographed through silica gel 60 (230-400 mesh).

\section{General Procedure for the Synthesis of Triazolines Using Method B}

The alkene $(1 \mathrm{mmol})$ and azide $(1.5 \mathrm{mmol})$ were dissolved in $10 \mathrm{~mL}$ of $\mathrm{CHCl}_{3}$ in a singlenecked round-bottomed flask and stirred at $25^{\circ} \mathrm{C}$. The progress of the reaction was 
monitored by TLC or ${ }^{1} \mathrm{H}$ NMR for the disappearance of the alkene (typically 4 weeks), and the crude material was chromatographed through silica.

\section{General Procedure for the Synthesis of Triazolines Using Method C}

The alkene $(1 \mathrm{mmol})$ and azide $(1.5 \mathrm{mmol})$ were dissolved in $10 \mathrm{~mL}$ of $\mathrm{CHCl}_{3}$ in a singlenecked round-bottomed flask fitted with a condensor and heated to reflux in an oil bath (oil temp. $=80^{\circ} \mathrm{C}$ ). The progress of the reaction was monitored by TLC or ${ }^{1} \mathrm{H}$ NMR for the disappearance of the alkene (typically 3 days), and the crude material was chromatographed through silica.

\section{General Procedure for the Synthesis of Triazolines Using Method D}

The alkene $(1 \mathrm{mmol})$ and azide $(1.5 \mathrm{mmol})$ were dissolved in $10 \mathrm{~mL}$ of $\mathrm{PhCH}_{3}$ in a singlenecked round-bottomed flask fitted with a condensor and heated to reflux in an oil bath (oil temp. $=125^{\circ} \mathrm{C}$ ). The progress of the reaction was monitored by TLC or ${ }^{1} \mathrm{H}$ NMR for the disappearance of the alkene (typically 3-4 h), and the crude material was chromatographed through silica.

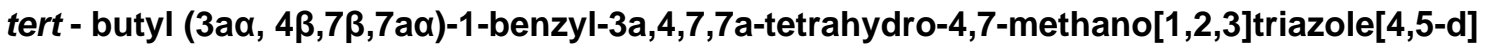

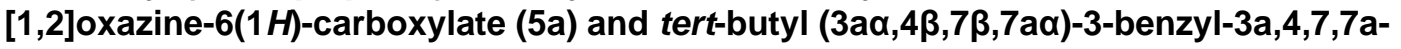
tetrahydro-4,7-methano[1,2,3]triazole[4,5-d][1,2]oxazine-6(3H)-carboxylate $(6 a)$

Prepared following the general procedure for the synthesis of triazolines using Method A. Cycloadduct 1a (198 mg, $1.01 \mathrm{mmol})$ and benzyl azide $(211 \mathrm{mg}, 1.58 \mathrm{mmol})$ were reacted for $48 \mathrm{~h}$. The brown crude material was chromatographed through $15 \mathrm{~g}$ of silica using a solvent gradient of $100 \% \mathrm{CH}_{2} \mathrm{Cl}_{2}$ to $98 \% \mathrm{CH}_{2} \mathrm{Cl}_{2} / \mathrm{EtOAc}$ to afford triazoline $\mathbf{6 a}$ (159 mg, $48 \%$ yield) as a white solid, then $85 \% \mathrm{CH}_{2} \mathrm{Cl}_{2} / \mathrm{EtOAc}$ to afford triazoline $\mathbf{5 a}(170 \mathrm{mg}, 51 \%$ yield) as a white solid ( $99 \%$ total combined yield). Analytical and x-ray crystallographic samples of $\mathbf{5 a}$ and $\mathbf{6 a}$ were prepared by recrystallization from EtOAc/hexanes. $\mathbf{5 a}$ : $\mathrm{mp}=$ $104-105{ }^{\circ} \mathrm{C} ; \lambda \max =255 \mathrm{~nm} ;{ }^{1} \mathrm{H}$ NMR $\left(500 \mathrm{MHz}, \mathrm{CDCl}_{3}\right) \delta 7.37-7.27(\mathrm{~m}, 5 \mathrm{H}), 4.92(\mathrm{~s}$, $1 \mathrm{H}), 4.90(\mathrm{~d}, J=14.5 \mathrm{~Hz}, 1 \mathrm{H}), 4.82(\mathrm{~d}, J=9.8 \mathrm{~Hz}, 1 \mathrm{H}), 4.72(\mathrm{~d}, J=14.5 \mathrm{~Hz}, 1 \mathrm{H}), 4.09(\mathrm{~s}$, $1 \mathrm{H}), 3.55(\mathrm{~d}, J=9.8 \mathrm{~Hz}, 1 \mathrm{H}), 1.70(\mathrm{dt}, J=11.4,1.5 \mathrm{~Hz}, 1 \mathrm{H}), 1.45(\mathrm{~d}, J=11.5 \mathrm{~Hz}, 1 \mathrm{H}), 1.39$ (s, 9H) ppm; ${ }^{13} \mathrm{C}$ NMR $\left(125 \mathrm{MHz}, \mathrm{CDCl}_{3}\right) \delta 156.4,135.6,128.8,128.24,128.17,84.6$, 82.6, 79.9, 61.2, 59.3, 53.4, 32.4, 27.9 ppm; HRMS (FAB), $m / z(\mathrm{M}+\mathrm{H})$ : calcd for $\mathrm{C}_{17} \mathrm{H}_{23} \mathrm{~N}_{4} \mathrm{O}_{3}{ }^{+}, 331.1770$; obsd, 331.1745. 6a: $\mathrm{mp}=100-101{ }^{\circ} \mathrm{C} ; \lambda \max =255 \mathrm{~nm} ;{ }^{1} \mathrm{H}$ NMR $\left(500 \mathrm{MHz}, \mathrm{CDCl}_{3}\right) \delta$ 7.35-7.24 (m, 5H), $4.92(\mathrm{~d}, J=14.7 \mathrm{~Hz}, 1 \mathrm{H}), 4.85(\mathrm{~s}, 1 \mathrm{H}), 4.84(\mathrm{~d}, J=$ $9.9 \mathrm{~Hz}, 1 \mathrm{H}), 4.61(\mathrm{~d}, J=14.7 \mathrm{~Hz}, 1 \mathrm{H}), 4.09(\mathrm{~s}, 1 \mathrm{H}), 3.50(\mathrm{~d}, J=9.9 \mathrm{~Hz}, 1 \mathrm{H}), 1.68(\mathrm{~d}, J=$ $11.5 \mathrm{~Hz}, 1 \mathrm{H}), 1.45-1.43(\mathrm{~m}, 10 \mathrm{H}) \mathrm{ppm} ;{ }^{13} \mathrm{C} \mathrm{NMR}\left(125 \mathrm{MHz}, \mathrm{CDCl}_{3}\right) \delta 156.4,135.6,128.8$, 128.3, 128.2, 83.7, 82.7, 79.6, 61.5, 59.9, 53.6, 32.3, 27.9 ppm; HRMS (FAB), $m / z(\mathrm{M}+\mathrm{H})$ : calcd for $\mathrm{C}_{17} \mathrm{H}_{23} \mathrm{~N}_{4} \mathrm{O}_{3}{ }^{+}, 331.1770$; obsd, 331.1753 .

\section{General Procedure for Photolysis of Triazolines. tert-butyl (1 $\alpha, 2 \beta, 4 \beta, 5 \alpha)-3-b e n z y l-6-$ oxa-3,7-diazatricyclo[3.2.1.0 2,4 ]octane-7-carboxylate (13)}

5a (333 mg, $1.01 \mathrm{mmol}$ ) was dissolved in $300 \mathrm{~mL}$ of degassed $\mathrm{CH}_{3} \mathrm{CN}$ and transferred to a 450-mL photochemical reaction vessel. The solution was irradiated in an immersion-well reactor under a stream of Ar with a Hanovia 450W mercury lamp equipped with a Vycor filter sleeve. Reaction progress was monitored by TLC and ${ }^{1} \mathrm{H}$ NMR for the disappearance of 5a. After $3 \mathrm{~h}$, the reaction was concentrated and the crude material was chromatographed through $30 \mathrm{~g}$ of silica using a gradient consisting of $100 \% \mathrm{CH}_{2} \mathrm{Cl}_{2}$ to $95 \% \mathrm{CH}_{2} \mathrm{Cl}_{2} / \mathrm{EtOAc}$ to afford $\mathbf{1 3}$ as a colorless oil (205 mg, 67\% yield). ${ }^{1} \mathrm{H}$ NMR (500 $\left.\mathrm{MHz}, \mathrm{CDCl}_{3}\right) \delta$ 7.35-7.27 $(\mathrm{m}, 5 \mathrm{H}), 4.79(\mathrm{~m}, 1 \mathrm{H}), 4.62(\mathrm{~m}, 1 \mathrm{H}), 3.40(\mathrm{~d}, J=13.5 \mathrm{~Hz}, 1 \mathrm{H}), 3.35(\mathrm{~d}, J=14.0 \mathrm{~Hz}, 1 \mathrm{H})$, 2.29-2.22 (m, 3H), $1.50(\mathrm{~s}, 9 \mathrm{H}), 1.39(\mathrm{~d}, J=10.5 \mathrm{~Hz}, 1 \mathrm{H}) \mathrm{ppm} ;{ }^{13} \mathrm{C} \mathrm{NMR}(125 \mathrm{MHz}$, $\left.\mathrm{CDCl}_{3}\right) \delta 157.5,138.6,128.4,127.7,127.3,82.3,79.9,60.7,59.1,37.1,36.7,29.4,28.2$ 
ppm; MS (FAB) m/z 303 (M+H), 247, 203, 171 (100\%); HRMS (FAB) $m / z(M+H):$ calcd for $\mathrm{C}_{17} \mathrm{H}_{23} \mathrm{~N}_{2} \mathrm{O}_{3}{ }^{+}, 303.1709$; obsd, 303.1712.

\section{Supplementary Material}

Refer to Web version on PubMed Central for supplementary material.

\section{Acknowledgments}

Support from the NIH (AI054193 and GM 68012) is gratefully acknowledged. The authors would also like to thank Jaroslav Zajicek for assistance with 2D-NMR experiments, Bill Boggess and Nonka Sevov for mass spectroscopic analyses, and Bruce Noll for X-ray crystallographic data. MJM gratefully acknowledges the Hans-Köll Institute and the University of Notre Dame for support of a sabbatical leave.

\section{References and Footnotes}

1. a Kirby GW. Chem. Soc. Rev. 1977; 6:1-24.b Corrie JET, Kirby GW, Mackinnon JWM. J. Chem. Soc., Perkin Trans. 1. 1985:883-886.c Leach AG, Houk KN. J. Org. Chem. 2001; 66:5192-5200. [PubMed: 11463273]

2. a Yamamoto Y, Yamamoto H. J. Am. Chem. Soc. 2004; 126:4128-4129. [PubMed: 15053601] b Kirby GW, Nazeer M. Tetrahedron Lett. 1988; 29:6173-6174.c Ritter AR, Miller MJ. J. Org. Chem. 1994; 59:4602-4611.

3. a Miller CA, Batey RA. Org. Lett. 2004; 6:699-702. [PubMed: 14986953] b Calvet G, Dussaussois M, Blanchard N, Kouklovsky C. Org. Lett. 2004; 6:2449-2451. [PubMed: 15228301] c Ware RW, Day CS, King SB. J. Org. Chem. 2002; 67:6174-6180. [PubMed: 12182658] d Ware RW Jr. King SB. J. Org. Chem. 2000; 65:8725-8729. [PubMed: 11112595]

4. Vogt PF, Miller MJ. Tetrahedron. 1998; 54:1317-1348.

5. a Shireman BT, Miller MJ. Tetrahedron Lett. 2000; 41:9537-9540.b Keck GE, Wager TT, McHardy SF. Tetrahedron. 1999; 55:11755-11772.c Keck GE, McHardy SF, Wager TT. Tetrahedron Lett. 1995; 36:7419-7422.

6. a Li F, Warshakoon NC, Miller MJ. J. Org. Chem. 2004; 69:8836-8841. [PubMed: 15575765] b Malpass JR, Hemmings DA, Wallis AL, Fletcher SR, Patel S. J. Chem. Soc., Perkin Trans. 1. 2001:1044-1050.c Justice DE, Malpass JR. Tetrahedron. 1996; 52:11977-11994.

7. a Li F, Brogan John B, Gage Jennifer L, Zhang D, Miller Marvin J. J. Org. Chem. 2004; 69:45384540. [PubMed: 15202916] b Kim K-H, Miller MJ. Tetrahedron Lett. 2003; 44:4571-4573.c Li H, Miller MJ. J. Org. Chem. 1999; 64:9289-9293.

8. a Jiang MX-W, Warshakoon NC, Miller MJ. J. Org. Chem. 2005; 70:2824-2827. [PubMed: 15787579] b Lee W, Miller MJ. J. Org. Chem. 2004; 69:4516-4519. [PubMed: 15202910]

9. a Surman MD, Mulvihill MJ, Miller MJ. J. Org. Chem. 2002; 67:4115-4121. [PubMed: 12054945] b Surman MD, Mulvihill MJ, Miller MJ. Tetrahedron Lett. 2002; 43:1131-1134.c Surman MD, Miller MJ. J. Org. Chem. 2001; 66:2466-2469. [PubMed: 11281789] d Mulvihill MJ, Surman MD, Miller MJ. J. Org. Chem. 1998; 63:4874-4875.

10. Lee W, Kim K-H, Surman MD, Miller MJ. J. Org. Chem. 2003; 68:139-149. [PubMed: 12515472]

11. Surman MD, Mulvihill MJ, Miller MJ. Org. Lett. 2002; 4:139-141. [PubMed: 11772110]

12. Keck GE, Webb RR, Yates JB. Tetrahedron. 1981; 37:4007-4016.

13. Keck GE, Romer DR. J. Org. Chem. 1993; 58:6083-6089.

14. a Shireman BT, Miller MJ. J. Org. Chem. 2001; 66:4809-4813. [PubMed: 11442409] b Nora GP, Miller MJ, Moellmann U. Bioorg. Med. Chem. Lett. 2006; 16:3966-3970. [PubMed: 16730172]

15. Quadrelli P, Mella M, Paganoni P, Caramella P. Eur. J. Org. Chem. 2000; 14:2613-2620.

16. a Braese S, Gil C, Knepper K, Zimmermann V. Angew. Chem., Int. Ed. 2005; 44:5188-5240.b Shea KJ, Kim JS. J. Am. Chem. Soc. 1992; 114:4846-4855.c Becker KB, Hohermuth MK. Helv. Chim. Acta. 1979; 62:2025-36.d Taniguchi H, Ikeda T, Imoto E. Bull. Chem. Soc. Jpn. 1978; 51:1859-65.e Scheiner P. Tetrahedron. 1968; 24:2757-66.f Scheiner P. J. Am. Chem. Soc. 1968; 
90:988-992.g Rolf H. Angew. Chem., Int. Ed. Engl. 1963; 2:565-598.h Tarabara IN, Kas'yan AO, Yarovoi MY, Shishkina SV, Shishkin OV, Kas'yan LI. Russ. J. Org. Chem. 2004; 40:992-998.

17. a Ishikura M, Katagiri N. Recent Res. Devel. Organic Chem. 2004; 8:197-205.b Ishikura M, Murakami A, Katagiri N. Org. Biomol. Chem. 2003; 1:452-453. [PubMed: 12926242] c Ishikura M, Kudo S, Hino A, Ohnuki N, Katagiri N. Heterocycles. 2000; 53:1499-1504.

18. Stout DM, Takaya T, Meyers AI. J. Org. Chem. 1975; 40:563-569.

19. Huenig S, Kraft P. Heterocycles. 1995; 40:639-652.

20. Zhang D, Sueling C, Miller MJ. J. Org. Chem. 1998; 63:885-888. [PubMed: 11672089]

21. Cicchi S, Goti A, Brandi A, Guarna A, De Sarlo F. Tetrahedron Lett. 1990; 31:3351-3354.

22. a Li F, Miller MJ. J. Org. Chem. 2006; 71:5221-5227. [PubMed: 16808509] b Sirisoma NS, Woster PM. Tetrahedron Lett. 1998; 39:1489-1492.

23. Alvarez SG, Alvarez MT. Synthesis. 1997:413-414.

24. Malpass JR, Belkacemi D, Griffith GA, Robertson MD. ARKIVOC. 2002:164-174.

25. Reymond J-L, Vogel P. Tetrahedron Lett. 1988; 29:3695-3698.

26. For a full description of the assignment of stereochemical relationships and the position of the $\mathrm{R}$ and Boc groups using 2D-NMR experiments, see the supporting information.

27. Peterson WR Jr. Arkles B, Washburne SS. J. Organomet. Chem. 1976; 121:285-291.

28. Pollex A, Hiersemann M. Org. Lett. 2005; 7:5705-5708. [PubMed: 16321027]

29. a Kolb HC, Finn MG, Sharpless KB. Angew. Chem., Int. Ed. 2001; 40:2004-2021.b Kolb HC, Sharpless KB. Drug Discovery Today. 2003; 8:1128-1137. [PubMed: 14678739]

30. a Narayan S, Muldoon J, Finn MG, Fokin VV, Kolb HC, Sharpless KB. Angew. Chem., Int. Ed. 2005; 44:3275-3279.b Klijn JE, Engberts JBFN. Nature. 2005; 435:746-747. [PubMed: $15944683]$

J Org Chem. Author manuscript; available in PMC 2011 September 11. 


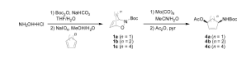

Scheme 1.

Synthesis of cycloadducts and protected amino alcohols. 


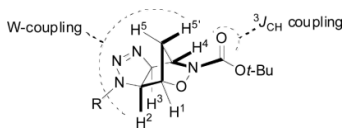

Figure 1.

Observed $\mathrm{W}$-coupling and ${ }^{3} \mathrm{~J}_{\mathrm{CH}^{-}}$-coupling of exo triazolines 
Scheme 2.

Reaction of 1 a to yield aziridines directly. 


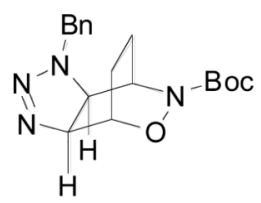

9
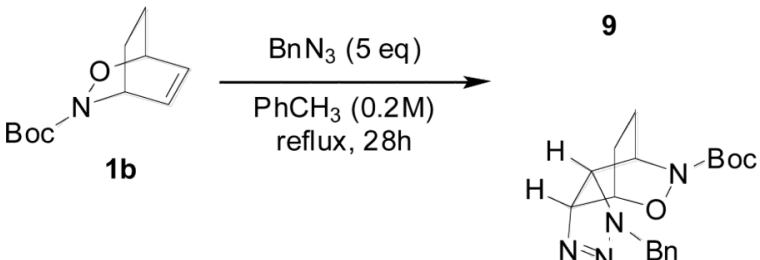

11<smiles>CC(C)(C)OC(=O)N1OC2CC1CCC2N1Cc2ccccc21</smiles>

10

$62 \%$ total yield exo: endo $=1.6: 1.0$

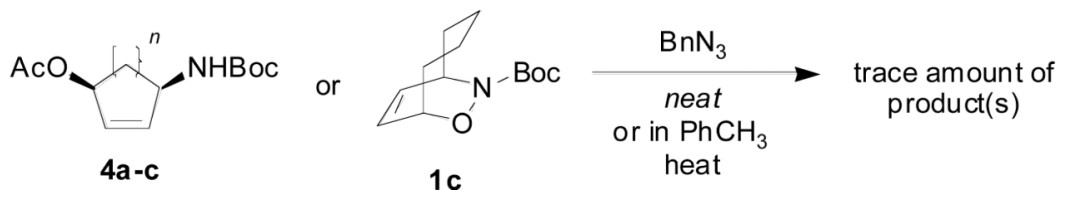

Scheme 3.

Reaction of other alkenes with benzyl azide. 


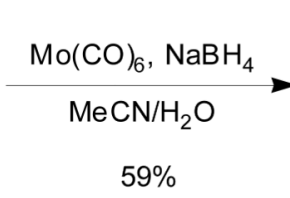

$59 \%$

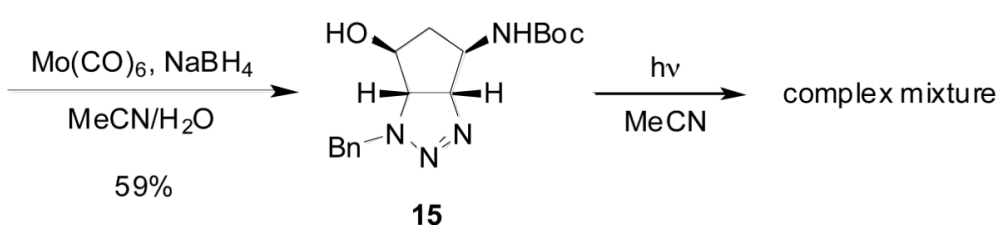

Scheme 4.

Structural elaboration of triazolines $5 \mathbf{a}$ and $6 \mathbf{a}$. 


\section{Table 1}

Reaction of 1a with various azides

\begin{tabular}{|c|c|c|c|c|}
\hline Entry & $\mathbf{R}$ & Conditions $^{a}$ & Products $^{b}$ & Yield $^{c}$ \\
\hline 1 & $\mathrm{Bn}$ & A & $5 \mathrm{a} / 6 \mathrm{a}$ & $99 \%$ \\
\hline 2 & $\mathrm{Bn}$ & B & $5 \mathrm{a} / 6 \mathrm{a}$ & $99 \%$ \\
\hline 3 & $\operatorname{Ad}^{d}$ & B & $5 b / 6 b$ & $95 \%$ \\
\hline 4 & $\mathrm{Bn}$ & $\mathrm{C}$ & $5 a / 6 a$ & $88 \%$ \\
\hline 5 & $n$-octyl & $\mathrm{C}$ & $5 c / 6 c$ & $99 \%$ \\
\hline 6 & cyclopentyl & $\mathrm{C}$ & $5 d / 6 d$ & $97 \%$ \\
\hline 7 & $\mathrm{Ph}$ & $\mathrm{C}$ & $5 e / 6 e$ & $97 \%$ \\
\hline 8 & $\mathrm{Bn}$ & D & $5 a / 6 a$ & $88 \%$ \\
\hline 9 & $n$-octyl & D & $5 c / 6 c$ & $81 \%$ \\
\hline 10 & cyclopentyl & D & $5 d / 6 d$ & $86 \%$ \\
\hline 11 & $\operatorname{Ad}^{d}$ & D & $5 b / 6 b$ & $85 \%$ \\
\hline 12 & $\mathrm{Ph}$ & D & $5 e / 6 e$ & $99 \%$ \\
\hline
\end{tabular}

${ }^{a} \mathrm{~A}=$ neat, $\mathrm{RT}, 2$ days; $\mathrm{B}=\mathrm{CHCl}_{3}, \mathrm{RT}, 4$ weeks; $\mathrm{C}=\mathrm{CHCl}_{3}$, reflux, 3 days; $\mathrm{D}=\mathrm{PhCH}_{3}$, reflux, $4 \mathrm{~h}$.

${ }^{b}$ Ratio of 5:6 $=1.0: 1.1$ in all cases as determined by ${ }^{1} \mathrm{H}$ NMR.

$c_{\text {Isolated yield. }}$

${ }^{d}$ Ad $=1$-adamantyl. 

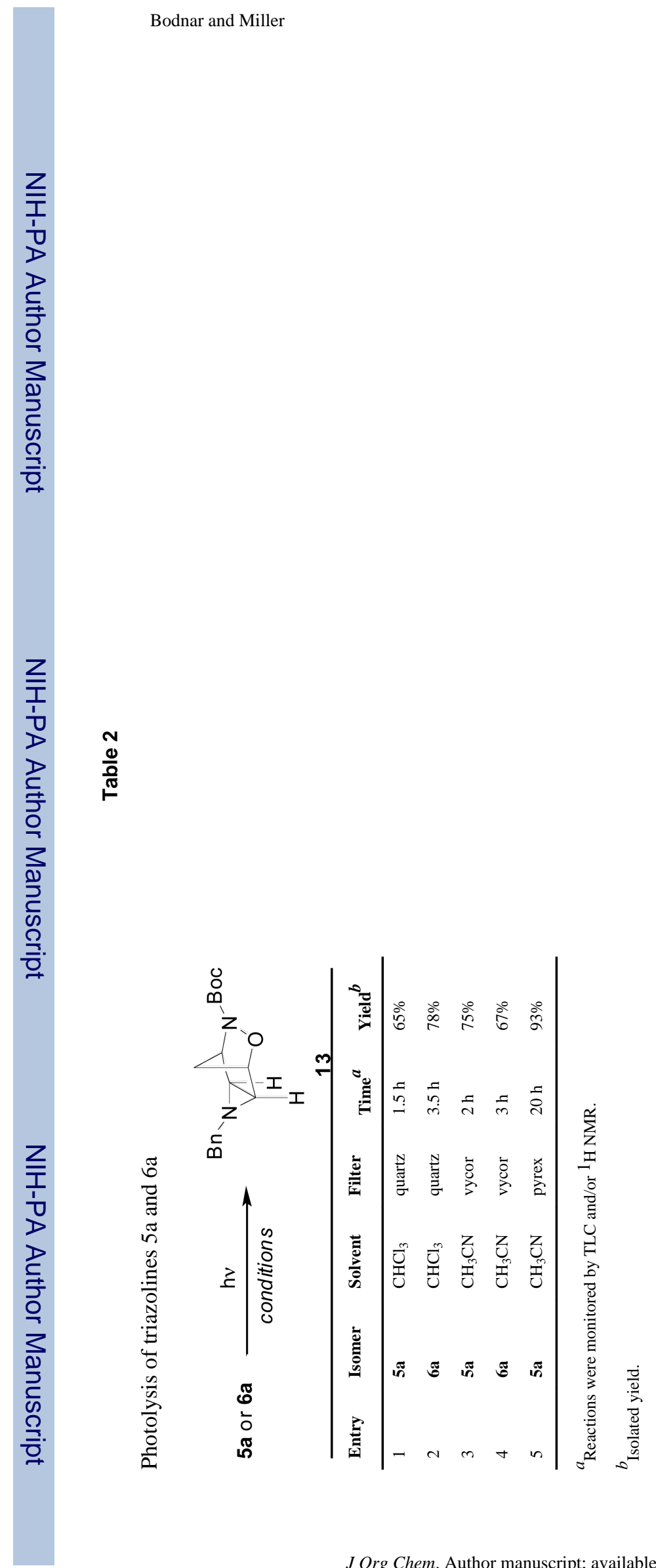

J Org Chem. Author manuscript; available in PMC 2011 September 11. 